\title{
LOW ENVIRONMENTAL IMPACT CONSTRUCTION: FRAGILITIES AND POTENTIALITIES OF HYPERADOBE AS A SOLUTION FOR THE BRAZILIAN HOUSING DEFICIT
}

\author{
Renata do Carmo Mota Alves ${ }^{1}$, Maria Gabriela Araújo Ranieri², Patrícia Capellato³, \\ Daniele Ornaghi Sant'anna ${ }^{4}$ \\ ${ }_{1}^{1}$ Unifei - Federal University of Itajubá, Development, Technology and Society Program (DTecS), Brazil, \\ E-mail: renata.cmalves@unifei.edu.br, ORCID: https://orcid.org/0000-0003-4440-4691 \\ 2 Unifei - Federal University of Itajubá, Institute of Production Engineering and Management, \\ Development, Technology and Society Program (DTecS), Brazil, E-mail: gabiranieri@unifei.edu.br, \\ ORCID: https://orcid.org/0000-0001-8631-020X \\ 3 Unifei - Federal University of Itajubá, Institute of Physics and Chemistry, Brazil. E-mail: \\ Pat capellato@yahoo.com.br, ORCID: https://orcid.org/0000-0002-6397-5820 \\ ${ }^{4}$ Unifei - Federal University of Itajubá, Institute of Natural Resources, Development, Technology and \\ Society Program (DTecS), Brazil, E-mail: ornaghi@unifei.edu.br, ORCID: https://orcid.org/0000-0003- \\ $\underline{0271-1693}$
}

\author{
ART ICLE INFO \\ Article history: \\ Received 2020-06-02 \\ Accepted 2020-12-12 \\ Available online 2020-12-12
}

Palavras-chave: Construção de baixo impacto ambiental. Déficit habitacional. Hiperadobe. Habitação de interesse social.

Keywords: Low environmental impact construction; Housing deficit; Hyperadobe; Social interest housing.

ABSTRACT. In the last five years, Brazil faces a housing deficit of around 6 million domiciles, while the contradictory 7 million unoccupied buildings. So far, neither the government nor the civil construction sector could resolve the issue, which is part of a graver picture with the environmental issues. Researches have been looking for a solution and the hyperadobe system, as a bagged earth construction system, presents many advantages for social interest constructions. Thus, the focus of this study is the fragilities and potentialities of hyperadobe's application in the national scenario, meaning to show it as a possible vector to solve the problem. Through the bibliographic review, it is concluded that the studied technology presents particularly advantageous characteristics to face the problem such as the low costs, the fast execution, the easy workforce training, and the high environmental performance in thermal and acoustical comfort. Therefore, is defended that the introduction of hyperadobe on the public policies on facing the housing deficit would be of great value, working on the difficulties that the system faces nowadays.

RESUMO. Há cinco anos o Brasil enfrentava um déficit habitacional na ordem de 6 milhões de domicílios, concomitantemente aos contraditórios mais de 7 milhões de imóveis desocupados. Tanto o Governo quanto o setor da construção civil mostram-se incapazes de solucionar a questão, que compõem um quadro ainda mais grave quando somada aos problemas ambientais. O hiperadobe é um sistema de construção com terra ensacada que apresenta diversas vantagens para construções de interesse social, de modo que este trabalho se debruça sobre suas potencialidades e problemas de utilização no cenário nacional, com o objetivo de mostra-lo como um possível vetor de enfrentamento da questão. Mediante revisão bibliográfica, conclui-se que a tecnologia estudada apresenta características que a tornam particularmente vantajosas no enfrentamento do déficit, como o baixo custo, a velocidade de execução, a simplicidade da capacitação de mão-de-obra e a alta performance ambiental em conforto térmico e acústico. Assim, defende-se que seria de grande valia a introdução do hiperadobe nas políticas públicas de enfrentamento do déficit habitacional, trabalhando, para tal, nas dificuldades que esse sistema construtivo enfrenta na atualidade. 


\section{Introduction}

The almost hegemonic view of the concept of development as economic growth, which has prevailed for decades in the bases of our society during the ascent of capitalism, resulted in radical transformations in the way the world produces and consumer goods and services, as well as the way there are 'defined' and 'sold' the standards of what is in the interests of production and consumption.

The changes in the feedstock, the production model, and the use of the final product made possible by the dominion of more sophisticated knowledge and technologies, radically marked the civil construction sector, as well as practically all sectors of human activity.

However, despite all the advances in modernization, the production of new buildings has not been equally distributed, and the housing deficit is yet another merciless social problem in the contemporary societies. In Brazil alone, according to the most recent report by the Fundação João Pinheiro, in 2015 the housing deficit was 6,355 million domiciles. The same report points to the contradiction between the lack of households and the fact that, according to PNAD, there are 7,906 million vacant properties, of which 6,893 million are in conditions to be occupied (FUNDAÇÃO JOÃO PINHEIRO, 2018).

Such a contradictory scenario is due, in large part, to local market effects such as real estate speculation, and is an important component that lay the foundation of Brazilian social exclusion, which is historical and ascendant since the nation's origin (RAMOS; NOIA, 2016)

The construction sector's mainstream pattern is equally incapable of attending the emergency housing demand. Environmental disasters, armed conflicts, climate change, and political restrictions are driving more and more people around the world into forced migration and/or emergency shelter. The temporary concentration camps are a big issue in the modern cities' dilemma, where the need for fast, efficient, safe, and cheap construction has not yet been addressed by the construction industry.

The mainstream construction systems are resultant from the massification of the standards presented as 'international quality'. They are responsible for a great environmental impact, unsustainable scales of natural resources' exploitation, and enormous energy expenditure from the material's manufacture to its utilization on-site. (EDWARDS, 2005; FERNANDES, 2013)

Due to the industrialization of civil construction and the development of increasingly advanced technologies, there is the disbelief that the earthen construction technology has suffered. However, construction systems with natural materials represent options with lower 
environmental impact, among which is the Earth Bags Construction system (EBC). (AZEVEDO; DUARTE, 2018)

The EBC system consists of modeling walls on-site, by pouring soil into bags and compacting one above the other, on each uniform line that overlaps the other to form the wall. Layer by layer, the compaction of the bags is made horizontally and vertically until it forms a monolithic block. Like the other modalities of EBC, the hyperadobe is a constructive system of low cost, high performance, and easy social appropriation - important characteristics to be considered when it comes to the construction of housing for needy and vulnerable populations.

Given the above, this paper aims to answer the following question: what are the weaknesses and potential of using hyperadobe as a solution vector for the Brazilian housing deficit? To this end, the argument is constructed through a analysis of the contemporary housing situation in the country, as well as a reflection on the advantages of the constructive technique and its implementation and application challenges.

\section{Material and methods}

This work uses the methodology of a bibliographic review of the major themes that connects the problems presented. To ensure realistic data was considered, consultations on budget reference tables in civil construction at the national level and housing financing programs of social interest promoted by the Brazilian government were also made.

\section{Results and discussion}

According to the Fundação João Pinheiro (2018), the housing stock is directly linked to the concept of housing deficit, therefore it can be understood as a deficit due to the replenishment of stock and deficit due to stock increase.

The Foundation's improvement in the calculating methodology for the housing deficit in different editions of the reports presented enabled a more realistic understanding of the national situation regarding sheltering. Concepts such as family cohabitation, precarious and inadequate housing, among others, contribute to an estimative of the number of lacking homes, as well as inadequate housing.

Of the 6,355 million households estimated to be in deficit in Brazil, in 2015, 87,7\% are located in urban areas, and $12,3 \%$ in rural areas, but this proportion of distribution differs in each region of the country (Fundação João Pinheiro, 2018), as seen in Graph 1. 


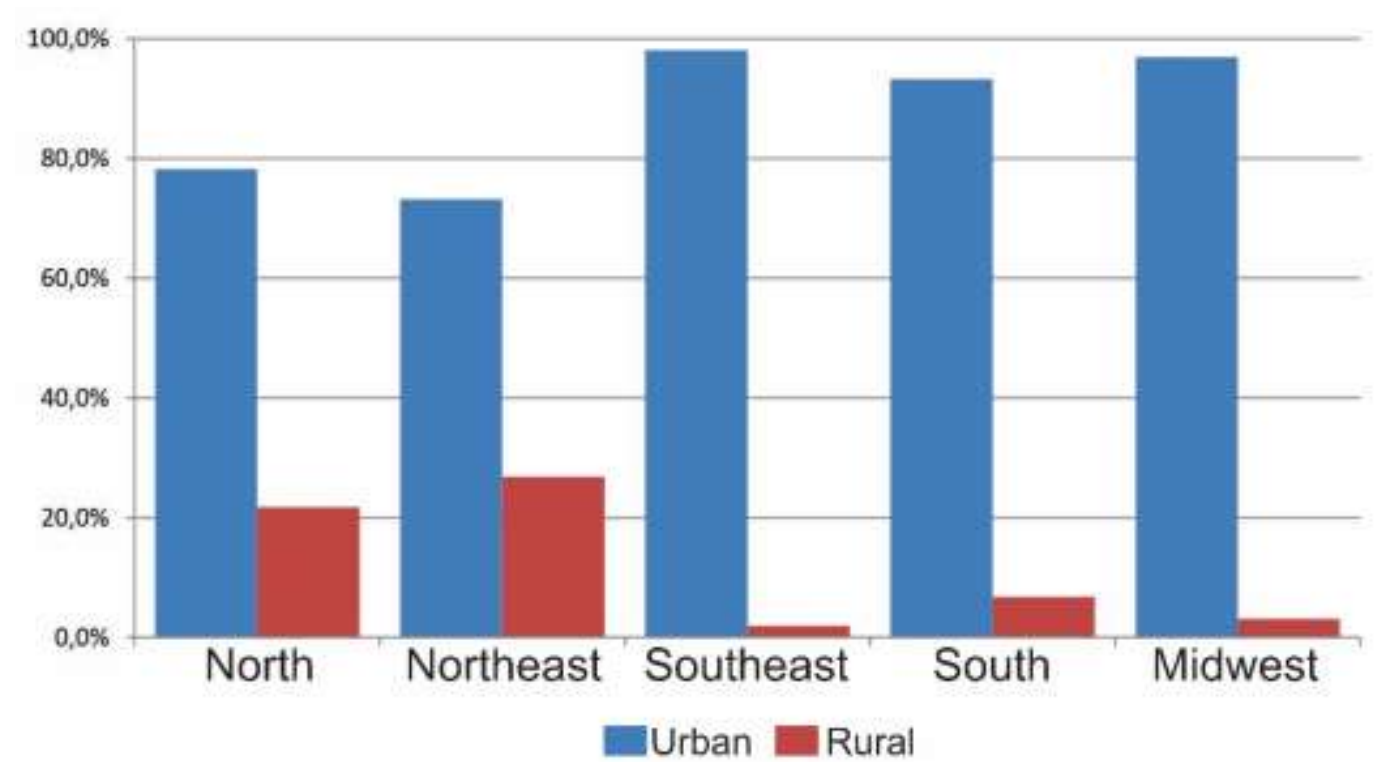

Graph 1 - Distribution of the Housing Deficit, by the household situation, according to geographic regions - Brazil - 2015.

Source: Fundação João Pinheiro, 2018, p.34 (translated by the author).

Despite its large size, the number of missing households is still lower than that of vacant ones. Of the estimated 7,906 million vacant properties in $2015,80,3 \%$ are in urban areas and $19,7 \%$ in rural areas. Of the total, 6,893 million properties were considered in conditions to be inhabited. (FUNDAÇÃO JOÃO PINHEIRO, 2018)

The wide-open contradiction between the housing deficit and the stock of vacant habitable properties is yet another factor that proves the inability of the current model that the civil construction sector has to solve this problem. The housing industry is unable to produce and distribute quality housing to the vulnerable population, and it has a possible lack of interest in unfolding the problem and coming up with a solution.

The previously mentioned 2018 report also highlights the impossibility of obtaining further details on the conditions and social suitableness of the buildings. It emphasizes the need for supplementary studies that allow the analysis of the housing situation with greater exactitude in the households' profile and the populations' housing scarcity.

Several researchers from different national entities and areas of knowledge have dedicated to the study of the housing issue in Brazil. The researches address both problems in government social housing programs, as well as the assessment of environmental comfort conditions, spatial suitability, and social insertion of housing units delivered to the poor.

The Brazilian housing policy has a history of several changes in the intervention models adopted by the government, and the housing problem goes back to the origins of the colonization of the territory (RAMOS; NOIA, 2016). In the last decades, state actions to counter the housing deficit took on new proportions since the Vargas Era with the construction of the 
Workers Villages, followed, from 1964 forward, by the production of low-quality and insipid architecture, regardless of the construction site. The political changes culminated in the current model employed by Caixa Econômica Federal and the Ministério das Cidades (which have been in operation since 1980 and 2003, respectively), through social programs such as the Programa Minha Casa Minha Vida (PMCMV), since 2009 (DREISSIG, 2020).

Among the adopted models' flaws and problems, the most common ones can be related to failures in the allocation and distribution of resources (RAMOS; NOIA, 2016). As noted by Bortoli and Villa (2020), many families are taking advantage of the opportunity to acquire their own homes through the PMCMV, but with the property comes some serious material and constructive problems, which can frequently compromise the environmental suitableness.

Case studies such as Santa Maria's social housing units show how the repetition of low-quality architectural types without criteria of spatial variety leads to great thermal discomfort for the residents. In addition to reducing their quality of life, it induces the inhabitants to use electrical equipment (when possible) to mitigate the negative effects of their houses. Such active thermal control measures, as well as being expensive at the time of purchase, it imposes a constant consumption of electricity, increasing family expenses. (GRIGOLETTI; LINCK, 2014)

Other studies show that the interest in debating the concepts of environmental sustainability and post-occupation personal savings on public policies is increasing. As a result, the measures already implemented on some social housing programs are rational usage and water collection; energy efficiency in civil construction; green walls; and certification of building materials (green seal) (DREISSIG, 2020). However, the most latent problems of environmental comfort, spatial suitability, and ecological impact are not sufficiently confronted with said measures, therefore a deeper reflection about the typologies built, the materials, and the construction systems chosen is relevant and necessary.

Addressing modern civil construction, Fernandes (2013) states that this sector is responsible for the consumption of 50 to $75 \%$ of the planet's natural resources, in addition to $40 \%$ of energy consumption and the production of $40 \%$ of global $\mathrm{CO} 2$ emissions. Edwards (2005), on the other hand, attributes to the construction industry $50 \%$ of world resource consumption, becoming one of the least sustainable activities on the planet.

Two major disturbing consequences can be observed when analyzing the globalization of industrialized construction patterns: the widespread gigantic environmental damage caused by the sector's production chain; and the loss of local knowledge rooted in different cultures, along with the systems, technologies, and solutions developed in each region to meet the needs of the local environment.

Both consequences are major problems today. Regarding environmental degradation, scientific studies dating from the 1960's forward have already proven, by various means, our predatory consumption of non-renewable resources at a fast pace, in addition to the planetary 
inability to regenerate itself, and the problems triggered by it in the distinct ecosystems affected. The construction sector will soon be facing logistics and restock problems with the materials used on a large scale around the world.

As for the loss of local knowledge problem, it is directly associated with housing problems, both in terms of household deficit and in the spatial unsuitableness of many occupied domiciles. The precious knowledge of techniques, materials, architectural and structural solutions, and the cultural and environmental resources towards the best ways to live and develop a region is being lost. The humanity forgets that the different communities' responses to the problem of housing is what allowed the construction of societies and guaranteed the security of this universal right, long before it receives that official status in modern times.

The rescue of easy cultural and social appropriation constructive knowledge, along with improvement and diffusion of low cost, high thermal and acoustic performance technology, which allows passive solutions for the housing spatial comfort, is of vital importance. It can assure vulnerable populations access to dignified housing and improvement in their life quality. Self-construction has guaranteed this right to thousands of people, for thousands of years, and could be playing a more relevant role facing the contemporary housing deficit.

To that end, the earthen construction presents itself as an ancestral technology that has been rescued today, which meets all the requirements that a constructive technology needs to have if it is to be a potential solution to the problems faced today. Versatile and of high-performance, the earth is the most comprehensive and best-distributed construction material around the globe. The material's easy access has allowed the development of numerous ways of using it in buildings. The knowledge produced, passed on, and transformed over time.

The earthen construction is part of the human occupation's history and the traditional constructive culture in all continents (GONÇALVES; GOMES, 2012). Besides the difficulty to measure how many clay habitations are in current use, several authors estimate that about a third of the world's population lives in earth houses (CHIRAS, 2000; REEVES; SIMS; CRIPPS, 2006; EVANS; SMITH; SMILEY, 2002; HALL; LINDSAY; KRAYENHOFF, 2012). Koch, Kunze and Seidl (2005) talk about 1,5 billion people. Minke (2001) confirms this information and states that, in developing countries, people living in earth houses came to represent $50 \%$ of the population, in that year. The author also says that the clay as a building material has lost its credibility due to the lack of knowledge of its wide possibilities. Ignorance leads to inappropriate use of these technologies.

Historically, there has been nearly an interruption in the evolution of earth construction, with the appearance of new construction technologies and materials, especially the use of cement and steel. With the construction processes' industrialization, building with clay became related to the lack of resources and access to technology. (SANTOS, 2015). 
Some advantages of using the soil as a building material are: humidity and temperature regulation inside the building; aerial contaminants absorption; radiation filtering; fire resistance and its propagation; earthquakes stability performance; some systems have structural capacity; its production of low environmental impact, since the material is $100 \%$ natural and reusable; the construction techniques are of easy popular appropriation; and finally, the execution's agility and the high performance in the construction site. Thus, the earthen construction systems are a great potential solution for building emergency shelters and communities in high seismic activity areas, in addition to building new settlements for resettled and refugee populations.

The versatility of use, aligned with the contemporary resumption of vernacular construction models, allowed the technological improvement and evolution of some of them. Among the building systems in use is the technique of Bagged Earth (BE). The term Bagged Earth encompasses all construction techniques that use bags as formwork to contain the soil before, during, and after compaction (SANTOS, 2015). Variations in the Bagged Earth Construction (BEC) technique are known by the informal names superadobe (KHALILI, 1999), hyperadobe, brickeradobe, earthbag building. (HUNTER; KIFFMEYER, 2004) and taipa ensacada (PROMPT, 2012).

The hyperadobe is a modality of BEC, derived from an exchange of bags used, being considered the most recent evolution of BEC. The improvement was proposed by the Brazilian engineer Fernando Soneghet who in 2006, working in partnership with the company Citropack (C), changed the type of bags used replacing the continuous woven polypropylene bags (PP-T) - used until then for BEC in the modality of superadobe - by continuous bags of high-density polyethylene mesh in Raschel mesh (HDPM-RM) as seen in Figure 1, calling this evolution hyperadobe. (SANTOS, 2015) The new bags are commercialized by Citropack @ by the name of biopack (CITROPACK).

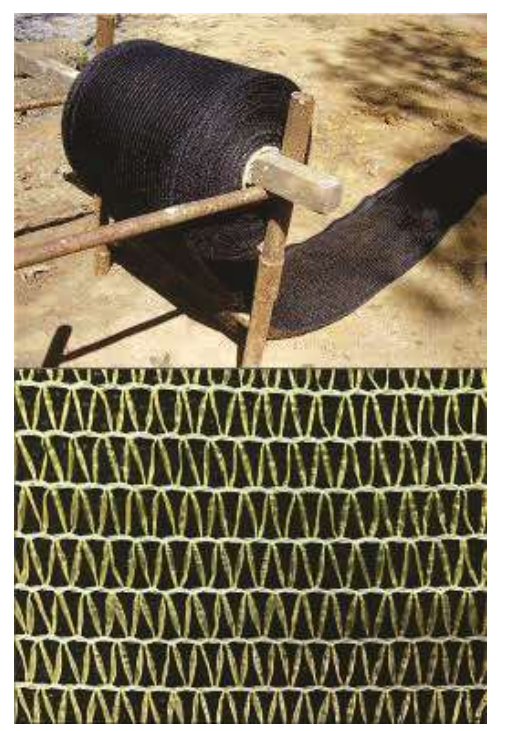

Figure 1 - Biopack roll (above) and the high-density polyethylene mesh in Raschel mesh (below) sold by Citropack @ .

Source: Citropack ( ). 
The construction system is simple to execute and consists of filling in continuous bags in loco with the soil, and its horizontal and vertical compaction, row by row, to build the walls as monolithic blocks, as seen in Figure 2. With hyperadobe the structures built can be made of straight-line walls, curve walls, or domes.

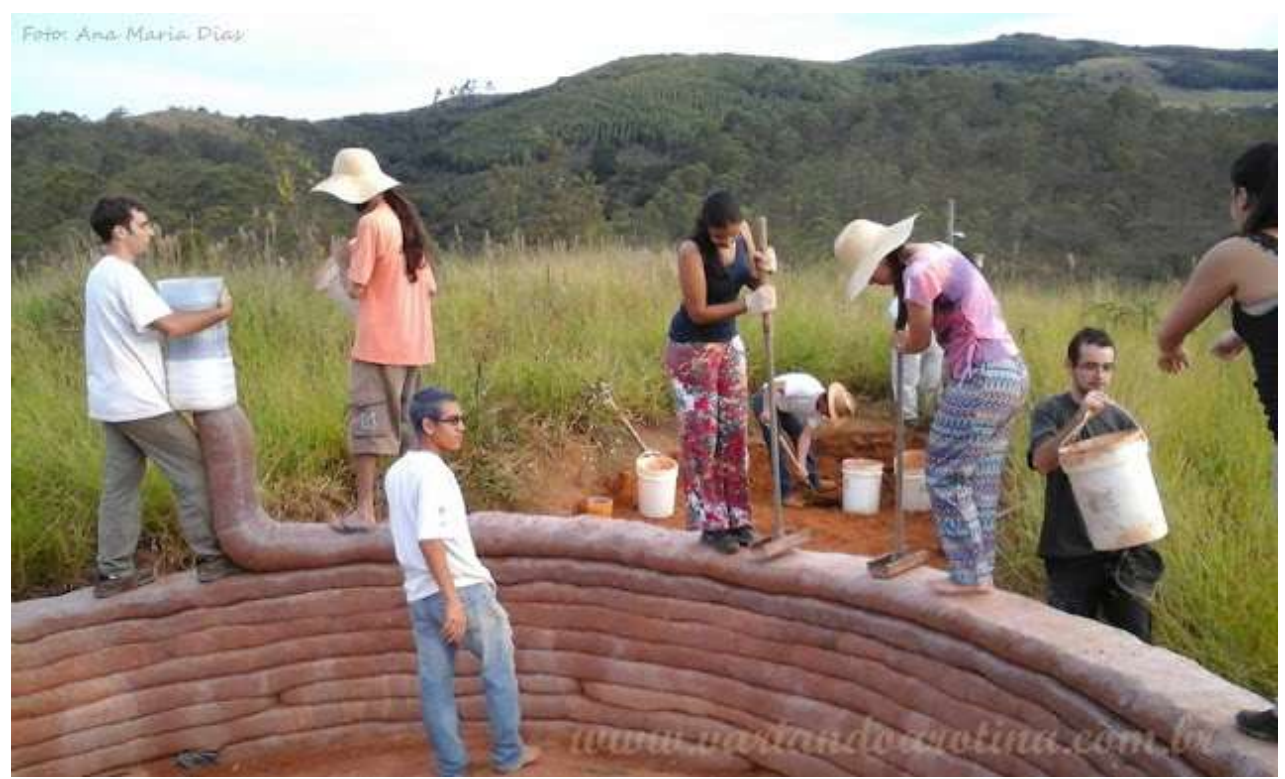

Figure 2 - Construction with hyperadobe - bag filling (workers on the left) and on-site compaction (on the right).

Source: Website Virando a Rotina (2015), accessed 06/16/2020.

By changing the bag used, the hyperadobe allowed to improve the superadobe solutions for the problems inherent to the structural functioning of the BECs. While the superadobe uses the application of barbed wire between the rows to provide adhesion and resistance to the shear force, the hyperadobe's bag, with its open net, allows the direct contact of the filling mass of one row with that of the other. This way, when compacting the rows vertically and horizontally, their adhesion is guaranteed by the contact between them, eliminating the intermediate barbed wire. Thus, the hyperadobe allows better framing of the BEC in the cradle-to-cradle model, as can be seen in Figure 3. 


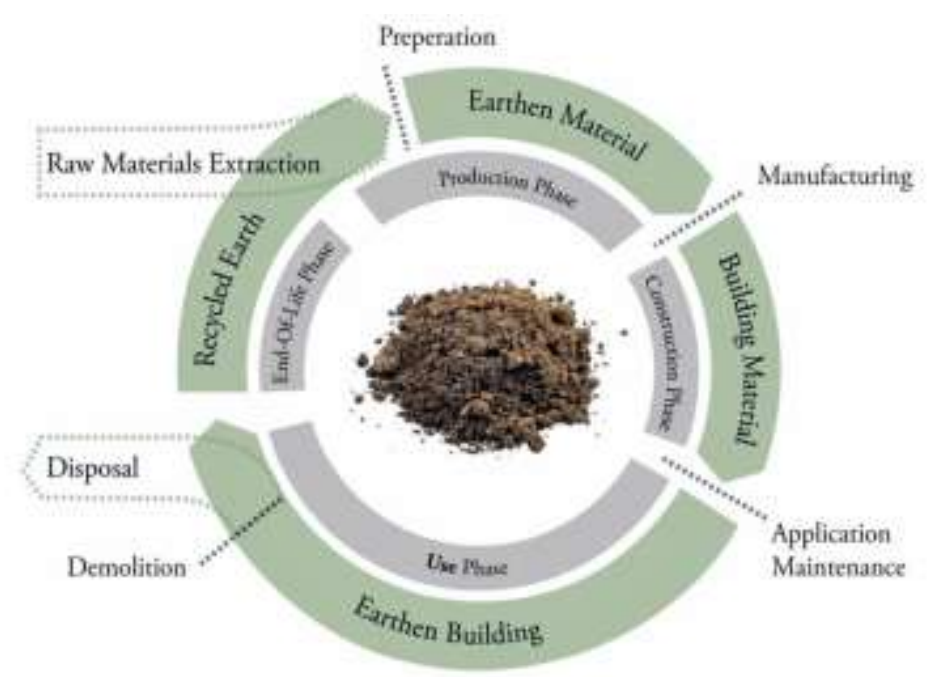

Figure 3 - Earthen building materials and methods - Life cycle diagram of earth as a building material.

Source: Ben-Alon; Loftness; Harries; Hameen; Bridges, 2020, p.90.

According to Azevedo and Duarte (2018), this construction system has been gaining adherents due to its practicality, structural resistance, and execution without the need for preassembly forms. Hunter and Kiffmeyer (2004) mention as the main advantages of EBC: the technology has already proven to be adaptable to seismic regions; there is no need to add straw; it is not necessary to wait for the bottom layer to dry; it allows for broader humidity parameters and less specificity in the type of soil mixture. Santos (2010 apud SANTOS, 2015) also states that, since its demolition process generates recyclable waste, the exclusive environmental impacts of non-mechanized bagged earth construction are related to obtaining and transporting the materials: earth, sacks and barbed wire when used. Thus, the estimated environmental impact of EBC is low.

Although not all types of soil are suitable for BEC, simple tests can be performed on the construction site to enable the identification and characterization of the soil as well as its granulometric correction by the addition of sand, and its stabilization by the addition of cement, when necessary. (NEVES; FARIA; ROTONDARO; CEVALLOS; HOFFMAN, 2009)

This construction system's characteristics, its execution advantages, and thermalacoustic performance are factors that attract research on the use of BEC in social housing. Comparative studies between conventional masonry, structural masonry, and BEC in the superadobe modality have already been carried out and show the advantage of BEC in terms of cost.

In a case study carried out by Dias (2015), a comparison of costs was made about the construction of a $43,11 \mathrm{~m}^{2}$ type of social interest housing in the city São José dos Campos-SP. The comparison was made between a structural block of concrete, superadobe with purchased soil and superadobe with the soil removed from the site. A savings of $13 \%$ was observed in 
the total budget of the superadobe with soil purchased, and $18 \%$ of the superadobe with the soil removed from the site, compared to the budget foreseen for construction with a concrete block. According to the author, these amounts would mean savings of $R \$ 504.677,00$ and $R \$ 715.137,00$, respectively, in the construction of 100 units in a social housing set.

The case study carried out by Queiroz and Oliveira (2019), for a typology of $32,35 \mathrm{~m}^{2}$ in Anápolis-GO, the difference in cost between the construction with conventional masonry of ceramic blocks and the superadobe with purchased soil was $9,56 \%$ in favor of the superadobe. The authors also emphasize that because of the technique non-restrictions concerning a specialized workforce, it can be easily performed on a large scale. An example of the potential money-saving is the construction of 50 houses using the superadobe, in a social complex, which would represent a total saving of approximately $R \$ 213.615,00$.

In both case studies, the authors concluded that the considerable reduction in the total cost for the superadobe system was due to the low cost of the main raw material for the work, the soil. In current values, the civil construction costs' table of the Sistema Nacional De Pesquisa De Custos E Índices Da Construção Civil (SINAPI) for May 2020 shows the cost of "clay or clay for landfill/backfill (with transport up to $10 \mathrm{~km}$ )" of $R \$ 28,35 / \mathrm{m}^{3}$, the cost of $\mathrm{R} \$ 16,34 / \mathrm{m}^{3}$ of "clay or clay for landfill (removed from the deposit, without transportation)", and the cost of $R \$ 66,67 / \mathrm{m}^{3}$ of "average sand - deposit/supplier post (removed from the deposit, without transportation)" (BRAZIL, 2020, translated by the author). These are low values for construction materials.

The estimates made for superadobe in social housing are promising and can be a reference for similar studies in hyperadobe. Another promising data is the average value of $\mathrm{R} \$ 310,00 / \mathrm{m}^{2}$ found in a comparison of 5 hyperadobe constructions in different locations in the country, in 2014. The value is well below the national average in the same year, which was $\mathrm{R} \$ 670,00 / \mathrm{m}^{2}$. The compared buildings were built in an assisted self-construction organization, with the help of volunteers and task force. (SANTOS; LIBRELOTTO; JACINTHO, 2014) The national average value for buildings in the category $\mathrm{RP} 1 \mathrm{Q}$ - Popular single-family residence in May 2020 is $R \$ 1.529,85 / \mathrm{m}^{2}$ (SINDUSCON - MG, [s.d.]).

Despite the advantageous characteristics of the material, the simplified construction process, the application possibilities, the social, economic, and environmental potential of EBC, the popularization of its use still faces practical and legal barriers.

Among the main difficulties experienced by builders is the lack of skilled labor-force not only workers at the construction site but also professionals capable of designing and supervising the execution of a low impact building, since the land use as a construction material is not widely taught in university courses in Brazil -, the absence of specific tools and machinery for the construction system, and scarcity of norms and codes that regulate the practice. The 
lack of official definitions on safety parameters for these constructions, make it difficult to frame this type of work in social housing finance programs.

Faced with these challenges, the countless active groups of builders, researchers, institutes, and enthusiasts seek to solve the deficiencies experimentally, adding empirical knowledge from their works to the experienced by other groups. As for the lack of trained workers, it is common for BEC endeavor to employ work models that involves the training of volunteers during the construction process, guided by a small team of experienced professionals who propose to teach the method in the field. construction site. There is also the initiative of private institutes and non-governmental organizations to promote experiences and training courses based on the same model.

The absence of specific machinery and tools results in the need to adapt objects that are intended for other activities or other construction systems. Additionally, the use of greater manual force in applied, which causes the use of a greater number of people for the job, this being the main reason why many BEC projects choose volunteer participation. However, owners and builders report the difficulty in managing large groups of volunteers in the work process. (SANTOS; LIBRELOTTO; JACINTHO, 2014)

The lack of regulations problem has been the most difficult to adapt. In Brazil, as in other countries, the lack of a technical standard that recognizes the construction system leads to restricting the constructions to the rural area, where there is no need for the approval of the Architectural Project by the City Hall, nor the emission of a term of technical responsibility by regulatory agencies such as CREA (Conselho Regional de Engenharia e Agronomia) and CAU (Conselho de Arquitetura e Urbanismo). Also, the lack of regulation for BEC makes it difficult for its propagation and acceptance by the population, giving the designers and builders working with BEC a very small share of the civil construction market.

Although there have been researches that investigate and attest to physical properties, constructive features, structural performance, and other aspects related to BEC - and more specifically to the superadobe - for at least 40 years, the translation of these results into standards, codes, and laws is still moving forward slowly around the world. Some countries already have other earth-based building systems in their regulatory codes, such as Germany, the United States of America, France, India, Peru, Turkey, Zimbabwe, and Brazil, however, the range of techniques is small, focusing on adobe, blocks of compressed earth and clay. (DELGADO; GUERREO, 2005)

In addition to all these factors, the use of hyperadobe as a constructive system to address the housing deficit also encounters a classificatory character barrier. According to the Fundação João Pinheiro, the methodology used to calculate the deficit and inadequacy of housing takes into account the so-called "rustic households" - an IBGE concept that classifies homes "without masonry walls or rigged wood. Due to its unhealthy conditions, this type of 
building causes discomfort and poses a risk of contamination by diseases." (FUNDAÇÃO JOÃO PINHEIRO, 2018).

According to this classification, the hyperadobe construction could fit into rustic households. However, the association of the walls' descriptions that are not made of masonry or wood with unhealthy conditions and diseases goes back to outdated concepts and remaining prejudices. The unhealthiness, diseases, and physical degradation are consequences to which any poorly executed building is subject, whether it be reinforced concrete, masonry, wood, or earth.

More importantly, the hyperadobe's introduction to the governmental social programs would mean a significant change in the whole interpretation of the meritocratic argument that supports the policies. So far, the social habitation for the ones who need it has been assigned to the smallest urban sites there are, on the argument that the poorest need less space. The small site induces bad housing constructions, with small and badly organized rooms. Hence, the house building with a construction technology that demands thicker walls would need bigger space and, consequentially, have the opportunity to offer bigger possibilities for the families inside their urban site of a dignified size.

\section{Conclusion}

Today's Brazilian housing situation is contradictory and impressive. Despite raw materials and workforce abundance, the country is unapt to solve its housing deficit. Even though the public policies and programs adopted by the Government in the last decades had the intent to benefit families with decent housing, they have (and continue to) shown themselves incapable of reflecting about and producing buildings that are worthy of housing status. The homes delivered to the population in social habitation complexes have little or no thermal-acoustic comfort, are of very low quality, and are disconnected from their context since their site is usually in a spatial segregation area in cities.

Also, the high levels of environmental degradation, as well as the accelerated natural resources consumption, by the conventional civil construction chain is alarming and its consequences are sadly tangible in the Brazilian territory, affecting thousands of families.

We must think of efficient technologies and public policies, which can make it possible to face both problems. A whole new approach needs to be developed to attend public and sustainable demands, starting which drastic changes in the construction systems to options with low environmental impact, bringing the additional benefit of improving spatial quality and environmental comfort for residents.

Undoubtedly, BEC presents itself as a viable option and with tangible additional benefits. If applied efficiently and strategically, the use of hyperadobe to face the Brazilian 
housing deficit has the potential to become a flagship in the production of adequate housing for the needy population.

Despite the barriers in the current scenario, the potential of this technology cannot be ignored. Therefore, other studies in the area are of vital importance to support public policies, regulations, creation of tools and machinery that enable the best use of the hyperadobe.

Furthermore, the rescue of constructive knowledge, good practices and safety procedures teaching among the population is a cultural factor that must be promoted. Selfconstruction is a popular tool for survival that has ensured access to the housing right throughout human history, and its recent neglect directly affects thousands of people.

The hyperadobe, with its accessible construction system, reduced cost, and suitability for collective work, is a technology with great social potential. The construction system allows the application in government-assisted self-construction programs, carrying out the construction of quality social habitation neighborhoods, through coordinated task forces.

The dissemination of construction process knowledge collectively, in addition to involving the beneficiaries in the process of building their homes, allows the training of the quality workforce, which can trigger future professional occupations for these people. Thus, the adequacy of public social housing programs and policies to incorporate the use of the hyperadobe can generate hundreds, if not thousands, of new jobs, attending to another serious social problem in the country, the mass unemployment.

Given the bibliographic review carried out and the arguments presented, it is concluded that the potential of using the hyperadobe as a solution to the Brazilian housing deficit is strong enough to justify investment in research and production of technologies, regulations, and public policies to overcome the weaknesses found in the present.

\section{Acknowledgement}

Acknowledgments to the Fundação de Amparo à Pesquisa do Estado de Minas Gerais - FAPEMIG for granting a scholarship to Renata do Carmo Mota Alves, which made this work possible.

\section{References}

AZEVEDO, Bruno; DUARTE, Flávio. Construção com Hiperadobe: Manual de Terra Ensacada - vol. básico. 2018. Disponível em: <http://www.biohabitate.com.br/materiais-paradownload/>. Acesso em: 06 out. 2019.

BEN-ALON, L.; Loftness, V.; Harries, K. A.; Hameen, E. C.; Bridges, M. INTEGRATING EARTHEN BUILDING MATERIALS AND METHODS INTO MAINSTREAM CONSTRUCTION. Journal of Green Building, v. 15, n. 1, p. 87-106, 1 jan. 2020. 
BORTOLI, K. C. R. DE; VILLA, S. B. Adequação ambiental como atributo facilitador da resiliência no ambiente construído em Habitações de Interesse Social. Ambiente Construído, v. 20 , n. 1 , p. $391-422$, mar. 2020.

BRASIL. SINAPI - SISTEMA NACIONAL DE PESQUISA DE CUSTOS E ÍNDICES DA CONSTRUÇÃO CIVIL 1. [s.l: s.n.].

CHIRAS, D. D. The Natural House: A Complete Guide to Healthy, Energy-efficient, Environmental Homes. Chelsea Green Pub., 2000. ISBN 9781890132576. Disponível em: <http://books.google.com.br/books?id=z_Y2AObA-joC>.

DELGADO, C. J.; GUERREO, I. C. INVESTIGACIÓN INTERNACIONAL DE NORMATIVA PARA CONSTRUCCIÓN CON TIERRA. Primero Congreso -Taller Internacional para la Normalización de la Arquitectura de Tierra. Anais...Tampico, México: 2005

\section{DIAS, G. D. VIABILIADDE TÉCNICA E ECONÔMICA DO SUPERADOBE NA CONSTRUÇÃO DE CASAS POPULARES. Guaratinguetá: UNESP, 2015.}

DREISSIG, A. H. A. AS CONTRIBUIÇÕES DA CONSTRUÇÃO CIVIL PARA UM DESENVOLVIMENTO SUSTENTÁVEL: TÉCNICAS, MATERIAIS E PROPOSTAS DE HABITAÇÃO SOCIAL SUSTENTÁVEL NO BRASIL. In: MACHADO, M. I. (Ed.). . Diálogo conceitual e metodológico das ciências sociais aplicadas com outras áreas do conhecimento 2 [recurso eletrônico]. Ponta Grossa - PR: Editora Atena, 2020.

EDWARDS, Brian. O guia básico para a sustentabilidade. 2. ed. Londres: Riba Enterprises, 2005. $226 \mathrm{p}$

EVANS, I.; SMITH, M.; SMILEY. The Hand-sculpted House: A Philosophical and Practical Guide to Building a Cob Cottage. Chelsea Green Publishing Company, 2002. ISBN 9781890132347. Disponível em: <http://books.google.com.br/books?id=tGEmmolyeSUC>.

FERNANDES, J. M. Uma casa construída em apenas duas horas. Obra24horas. On line 2013.

FUNDAÇÃO JOÃO PINHEIRO. Estatística e Informações: demografia e indicadores sociais - Déficit Habitacional no Brasil 2015 (Diretoria de Estatística e Informações (DIREI), Ed.)Belo HorizonteFundação João Pinheiro, , 2018.

GONÇALVES, T. D.; GOMES, M. I. CONSTRUÇÃO DE TERRA CRUA: POTENCIALIDADES E QUESTÕES EM ABERTO. Engenharia para a sociedade - investigação e inovação. Anais...Lisboa: LNCE, jun. 2012Disponível em: <https://www.researchgate.net/publication/268352912>. Acesso em: 25 abr. 2020

GRIGOLETTI, G. DE C.; LINCK, G. I. Análise de comportamento térmico de HIS térreas unifamiliares em Santa Maria, RS. Ambiente Construído, v. 14, n. 2, p. 109-123, jun. 2014.

HALL, M.; LINDSAY, R.; KRAYENHOFF, M. . Modern Earth Buildings: Materials, Engineering, Constructions and Applications. Elsevier Science, 2012. ISBN 9780857096166. Disponível em: <http://books.google.com.br/books?id=YYBwAgAAQBAJ>.

HUNTER, K.; KIFFMEYER, D. Earthbag Building The Tools, Tricks and Techniques. Gabriola Island, Canada: New Society Publishers, 2004.

KHALILI, E. N. EARTHQUAKE RESISTANT BUILDING STRUCTURE EMPLOYING SANDBAGS, 10 ago. 1999.

KOCH, G.; KUNZE, C.; SEIDL, J. . CONSTRUCTION - FROM A NICHE PRODUCT TO AN INDUSTRIAL BUILDING SYSTEM. SB05 Tokyo: The 2005 World Sustainable Building 
Conference. Rotterdam (Netherlands): in-house publishing: p.1270-1275 p. 2005.

MINKE, G. Manual de construcción para viviendas antisísmicas de tierra. Forschungslabor für Experimentelles Bauen Universidad de Kassel, 2001.

NEVES, C. M. M.; Faria, O. B.; Rotondaro, R.; Cevallos, P. S.; Hoffman, M. V. SELEÇÃO DE SOLOS E MÉTODOS DE CONTROLE NA CONSTRUÇÃO COM TERRA - PRÁTICAS DE CAMPO. [s.I.] Rede Ibero-americana PROTERRA, 2009.

PROMPT, C. H. Arquitetura de terra em unidades agrícolas familiares: estudo de caso no oeste catarinense. 2012. 176 (Dissertação). PósArq, Universidade Federal de Santa Catarina, Florianópolis-SC.

QUEIROZ, I. M. DE; OLIVEIRA, T. S. DE. ESTUDO COMPARATIVO ORÇAMENTÁRIO ENTRE SUPERADOBE E ALVENARIA CONVENCIONAL. Anápolis - GO: UNIEVANGÉLICA, 2019.

RAMOS, J. DA S.; NOIA, A. C. A Construção de Políticas Públicas em Habitação e o Enfrentamento do Déficit Habitacional no Brasil: Uma Análise do Programa Minha Casa Minha Vida. Desenvolvimento em Questão, v. 14, n. 33, p. 65-105, 2016.

REEVES, G. M.; Sims, I.; Cripps, J.C. . Clay Materials Used in Construction. Geological Society, 2006. ISBN 9781862391840. Disponível em: <http://books.google.com.br/books?id=iDqalaLe6lkC>.

SANTOS, C. A. DOS. Construção Com Terra No Brasil: Panorama, Normatização E Prototipagem Com Terra Ensacada. [s.I.] Universidade Federal de Santa Catarina, 2015.

SANTOS, C. A. DOS; LIBRELOTTO, L. I.; JACINTHO, C. Building with earth - Brazil's most popular raw earth building techniques and the opinion of experienced builders. Key Engineering Materials, v. 600, p. 123-131, 2014.

SINDUSCON - MG. CUB $/ m^{2}$ - Custos Unitários Básicos de Construção. [s.l: s.n.]. 